Original Research Paper

\title{
Effect of Slum Water on Physiology of Heteropneustes fossilis Collected from Silchar, Assam
}

\author{
${ }^{1}$ Rubina Roy, ${ }^{2}$ Bijoy Brahma, ${ }^{3}$ Satabdi Bhattacharjee and ${ }^{4}$ Soumitra Nath \\ ${ }^{1,2}$ Department of Zoology, Gurucharan College, Silchar, Assam, India \\ ${ }^{3}$ Institutional Biotech Hub, Gurucharan College, Silchar, Assam, India \\ ${ }^{4}$ Department of Biotechnology, Gurucharan College, Silchar, Assam, India
}

Article history

Received: 17-11-2018

Revised: 21-01-2019

Accepted: 09-02-2019

Corresponding Author:

Soumitra Nath

Department of Biotechnology,

Gurucharan College, Silchar,

Assam, India

Email: nath.soumitra1@gmail.com
Abstract: Poverty and overpopulation are not just prevailing in big cities, but have also become a matter of concern in small towns. Safe drinking water is considered a basic human need, yet millions of people do not have access to an adequate and safe water supply. The present study is focused on the quality assessment of water bodies of slum areas of Silchar, Assam, India and to evaluate the physiological stress on Heteropneustes fossilis from household water pollution. Water samples from six different sites were collected and their physical parameters were tested. Fishes $(n=35)$ of approximately similar size $(15.8 \pm 0.84 \mathrm{~cm})$ and weight $(30.0 \pm 1.2 \mathrm{gm})$ were exposed to each water samples for a period of 10 days and their morphological and behavioural changes were observed. The RBC and WBC counts of the fishes were also determined. Physical properties of the water samples revealed that the $\mathrm{pH}$ ranges from 4.79-6.10; conductivity 0.07-0.46 mS/cm; total dissolved solids 0.03-0.29 ppm; free $\mathrm{CO}_{2} 13-26$ ppm and dissolved oxygen 2.2-3.5 ppm. An abundance of bacteria was observed in the water samples and the predominant isolates were identified as Escherichia coli, Klebsiella sp., Bacillus sp. and Pseudomonas sp. Fishes exposed to pond water were initially active with no morphological and behavioural changes. However, from day-5 onwards, their swimming had become idle and lethargic, their dark black skin had gradually attained a pale texture and the mucus content of skin had gradually reduced. Despite providing food and air regularly, the fishes had gradually stopped eating, with swimming pattern changed from dorsal to ventral side upward and decreased opercular activity. Hematological studies showed decreased RBC count and increased WBC count in pond water treated fishes, inferring blood balance disturbance and infection in fishes. Adequate measures should be taken by the respective residents of the selected areas to minimise the degree of water contamination and use of proper disinfectants, or else the hazardous condition of the water will deteriorate the aquatic biodiversity and create serious health problems in humans.

Keywords: Slum Water, Heteropneustes fossilis, Haematological Indices, Coliform Bacteria

\section{Introduction}

Water is the vital asset for the entire living world. Every civilization begins nearby a water body. Human beings not only consume water but are also dependent on bathing, washing and all other kinds of household activities. Increase in population, lack of space, poverty and immigration has led to the flourishment of slum areas. Industrial wastes, unhygienic domestic activities and sanitation have a significant contribution in contaminating the water bodies (Bardach et al., 1965; Shiddamallayya and Pratima, 2008). The household sewage and harmful chemicals having inadequate treatment facilities may degrade the quality of the water bodies and make them unsuitable for human use. The aquatic organisms are adversely affected by water 
pollution. Fishes are not only the most diverse group of organism inhabiting the aquatic ecosystem but also the major contributor to the human diet (Khalili Tilami and Sampels, 2018). Though some fishes have the capability of surviving in the adverse situations, the high level of pollution in recent times has been giving a tough competition to the survivability of the fishes.

Heteropneustes fossilis (Asian stinging catfish) is a species of air sac catfish locally known as Shingi or Shing. $H$. fossilis is native to India, Bangladesh, Pakistan, Nepal, Sri Lanka, Burma and Thailand (Talwar, 1991). This species breeds in confined waters during the monsoon months but can breed in ponds, derelict ponds and ditches when sufficient rainwater accumulates (Puvaneswari et al., 2009). H. fossilis is of high economic importance and high demand because of its medicinal value (Talwar, 1991). It is considered to be highly nourishing and well preferred because of its less spine, less fat and high digestibility in many parts of the Indian subcontinent (Khan et al., 2003). The unhygienic practices and lack of knowledge in the concerned slum areas have led to the deterioration of the quality of nearby water bodies concerning the physical properties as well as the microbial diversity. As a result, diversity, number and survivability of the fishes have been significantly affected and the water has become nonconsumable and non-preferable for human use (Haseena et al., 2017). The contaminated water not only makes the fishes prone to pathogenic attack but may also lead to several water-borne diseases in human. The present study focuses on the assessment of water qualities, collected from six different sites of Silchar, Assam, India. The study also investigates the effect of water qualities on morphological and hematological indices of $H$. fossilis.

\section{Materials and Methods}

\section{Collection of Water Samples}

Water samples were collected from 6 different ponds of Cachar district, Assam, India. A preliminary survey was conducted by interacting with local residents to access the condition and use of water for the domestic purpose (Table 1). Water samples were collected in sterile bottles, properly packed, labelled and immediately bought to the laboratory for determining physical properties and bacterial diversity.

\section{Analysis of Physical Parameters}

Measurement of conductivity, Total Dissolved Solids (TDS) and $\mathrm{pH}$ were performed by Water and Soil Analysis Kit (Deluxe, Model LT- 60; ISO 9001: 2008). Free carbon dioxide $\left(\mathrm{CO}_{2}\right)$ and Dissolved Oxygen (DO) were determined by Winkler's method of performing titrations (APHA 1989). For determining dissolved oxygen, samples were fixed with $\mathrm{MnSO}_{4}$ and $\mathrm{KI}$ solutions and immediately brought to the laboratory. Water samples were also collected from Public Health Engineering (PHE), Silchar and were found to be in the permissible range, suitable for life forms. The water collected from PHE, Silchar act as a control for performing later experiment.

\section{Determination of Bacterial Diversity in Water}

About $1 \mathrm{~mL}$ of the five-fold serial dilution of water samples were inoculated in Mac Conkey (Kaper et al., 1978) and incubated at $37^{\circ} \mathrm{C}$ for 24 hours. The total bacterial colonies were counted in microprocessor colony counter and the distinct individual colonies were subcultured by streak plate method. The isolates were identified by Gram staining and biochemical tests (Indole, MR, VP, Citrate, Catalase and Oxidase test) (Cappuccino and Sherman, 1996).

\section{Toxic Effect of Effluents on Fish Growth}

Thirty-five $H$. fossilis of equal size $(15.8 \pm 0.84 \mathrm{~cm})$ and equal weight $(30.0 \pm 1.2 \mathrm{gm})$ were collected from local fisherman. Fishes were distributed in seven containers $\left(46 \times 40 \times 13 \mathrm{~cm}^{3}\right)$, containing water from six selected ponds. Fishes were also kept in a control container filled with water, collected from PHE, Silchar.

Table 1: Topography, location and use of pond water by the local residents

\begin{tabular}{|c|c|c|c|c|c|c|c|}
\hline Location & $\begin{array}{l}\text { Latitude/ } \\
\text { Longitude }\end{array}$ & $\begin{array}{l}\text { Use of water for } \\
\text { household purposes }\end{array}$ & Defecation & $\begin{array}{l}\text { Domestic } \\
\text { waste disposal }\end{array}$ & $\begin{array}{l}\text { Use of water } \\
\text { for drinking }\end{array}$ & $\begin{array}{l}\text { Use of } \\
\text { disinfectant }\end{array}$ & $\begin{array}{l}\text { Availability } \\
\text { of Fishes }\end{array}$ \\
\hline Malini Beel & $\begin{array}{l}24^{\circ} 83^{\prime} 36.7^{\prime \prime} \mathrm{N} / \\
92^{\circ} 78^{\prime} 09.6^{\prime \prime} \mathrm{E}\end{array}$ & Yes & Yes & Yes & Yes & No & $\begin{array}{l}\text { Small to } \\
\text { medium size }\end{array}$ \\
\hline Ashram Road & $\begin{array}{l}24^{\circ} 81^{\prime} 12.4^{\prime \prime} \mathrm{N} / \\
92^{\circ} 79^{\prime} 84.3^{\prime \prime} \mathrm{E}\end{array}$ & Yes & No & Yes & No & Yes & $\begin{array}{l}\text { Small } \\
\text { sized fish }\end{array}$ \\
\hline Deb Para & $\begin{array}{l}24^{\circ} 80^{\prime} 87.8^{\prime \prime} \mathrm{N} / \\
92^{\circ} 79^{\prime} 46.5^{\prime \prime} \mathrm{E}\end{array}$ & Yes & Yes & Yes & Yes & No & $\begin{array}{l}\text { Small } \\
\text { sized fish }\end{array}$ \\
\hline $\begin{array}{l}\text { Near Shishu } \\
\text { Mandir School }\end{array}$ & $\begin{array}{l}24^{\circ} 82^{\prime} 19.3^{\prime \prime} \mathrm{N} / \\
92^{\circ} 78^{\prime} 04.3^{\prime \prime} \mathrm{E}\end{array}$ & Yes & Yes & Yes & Yes & No & $\begin{array}{l}\text { Small } \\
\text { sized fish }\end{array}$ \\
\hline Tapaban Nagar & $\begin{array}{c}24^{\circ} 81^{\prime} 79.6^{\prime \prime} \mathrm{N} / \\
92^{\circ} 78^{\prime} 26.0^{\prime \prime} \mathrm{E}\end{array}$ & Yes & Yes & Yes & No & Yes & $\begin{array}{l}\text { Small to } \\
\text { medium sized }\end{array}$ \\
\hline Chirukandi & $\begin{array}{l}24^{\circ} 83^{\prime} 11.7^{\prime \prime} \mathrm{N} / \\
92^{\circ} 77^{\prime} 31.5^{\prime \prime} \mathrm{E}\end{array}$ & Yes & No & Yes & No & Yes & $\begin{array}{l}\text { Small to } \\
\text { medium sized }\end{array}$ \\
\hline
\end{tabular}


In each container, five fishes were exposed and observed for ten days. The fishes in each sample were provided artificial food and oxygen with the help of an aerator. After every 2-3 days, the water of each sample was changed by the stock water of the respective sample. Throughout the study period, the skin texture, swimming pattern and operculum movement and variations in the behaviour of Heteropneustes fossilis were noted. The $\mathrm{RBC}$ and WBC count of the fishes were determined.

\section{Determination of $R B C$ and WBC Count}

$\mathrm{RBC}$ and WBC count of the fishes were determined using haemocytometer, collected on day 0 , day 5 and day 10. Blood was obtained from the tail region of Heteropneustes fossilis, sucked into both the RBC and WBC pipettes up to 0.5 marks. In the RBC pipette, RBC diluting fluid was sucked up to 101 marks, shaken thoroughly to mix diluting fluid and blood and the final dilution becomes 200 times. While in the WBC pipette, WBC diluting fluid was sucked up to 11 marks, shaken thoroughly and the final dilution becomes 20 times. The mixtures were put to Neubauer's chamber one after another and covered with a coverslip maintaining a distance of 0.1 $\mathrm{mm}$ between the coverslip and the chamber. The slides were then visualized under microscope and RBCs and WBCs were counted (Poddar et al., 2002).

Haematological parameters were calculated by taking mean of two replicates from each group and is expressed as mean \pm standard deviation. However, on day 5 and day 10 , some containers showed total mortality and thus results cannot be obtained.

\section{Results and Discussion}

The survey conducted with the residents of the selected sites provides the information that water of six selected sites is used for all kinds of household purposes and disposal of wastes, four sites are used for human defecation purpose and three have never been disinfected. The survey also showed the availability of different types of fish from small to medium size. However, the number of fishes in each site has been decreasing gradually, according to the survey (Table 1). The normal $\mathrm{pH}$ range of pond water should be within 6.5-9.0 (Prajapati et al., 2018). It has been observed that the $\mathrm{pH}$ level of the water samples ranged from 4.79-6.10 (Table 2), which can provide stress to the survival and growth of fish as well as aquatic flora (Kawamura et al., 2015).

The degree of pollution of a water body can be assessed from the total amount of solids (ions) dissolved in it, which in turn determines its ability to conduct electricity. However, higher values of TDS and conductivity indicate a higher degree of pollution, while considerably lower values resemble an unsuitable environment for fish growth and survival. Electrical conductivity ranges from $0.07-0.46 \mathrm{mS} / \mathrm{cm}$, inferring that the water samples are in acceptable condition for the survival of aquatic fauna. Moreover, studies have revealed that the TDS in freshwater is usually 0.65 times the conductivity (Thirumalini and Joseph, 2009) to support diverse aquatic life. The water quality test of the selected ponds showed that the TDS was in the range of 0.03-0.29 ppm (Table 2).

Carbon-dioxide released by the aquatic fauna is used up by the phytoplankton for photosynthesis. Higher the amount of free $\mathrm{CO}_{2}$ in the water body, higher the survival rate of aquatic flora, making the environment highly toxic to the fishes (Khan et al., 2018). Free $\mathrm{CO}_{2}$ can be directly related to the oxygen dissolved in water. Usually water body containing a higher amount of DO will have a lesser amount of free $\mathrm{CO}_{2}$ (Wurts and Durborow, 1992). The present study subsequently reported a low level of $\mathrm{DO}$ and free $\mathrm{CO}_{2}$, thus contradicting the general correlation and indicating an ecological imbalance in the water. The free $\mathrm{CO}_{2}$ level of the studied ponds ranges from 13-26 ppm, with DO level ranging between 2.2-3.5 ppm (Table 2), indicating a high degree of pollution and unsustainable condition for fish life. Researchers have shown that catfish can tolerate $\mathrm{CO}_{2}$ level from 20-30 ppm provided the DO concentration is above 5 ppm (Wurts and Durborow, 1992).

Presence of faecal coliform bacteria in the water samples indicates disposal of human and other animal faeces and also indicates the presence of other pathogens in the water (Ksoll et al., 2007). However, for the maintenance of ecological balance, the presence of diverse types of beneficial bacteria is necessary, but within a reasonable range. According to WHO guidelines, pond water used for human consumption and household purposes should not contain more than 50 coliform bacteria per $100 \mathrm{~mL}$ of water (Culpepper et al., 2016). Total bacterial count ranges from $3.14 \times 10^{5}$ to $9.96 \times 10^{5}$ per $100 \mathrm{~mL}$ of water, indicating a high degree of faecal contamination and high chances of human beings and fishes being prone to water-borne diseases. The results of Gram staining and biochemical tests revealed the presence of Escherichia coli, Klebsiella sp., Bacillus sp. and Pseudomonas sp., (Table 3). This abundance of such bacteria indicates the deterioration of the aquatic ecosystem (Chakraborty and Bhadury, 2015; Köchling et al., 2017) and also the possibility of getting prone to the water-borne diseases (Cabral, 2010).

A healthy environment is an asset to the healthy morphology and behaviour of the aquatic organisms. The observations made within the ten days study revealed that all the fishes which were actively swimming had become idle and lethargic, decrease in body weight, attaining a pale texture and the mucus content of skin had gradually reduced. Despite providing food and air regularly, the fishes had gradually stopped eating, with swimming pattern changed from dorsal to ventral side upward and decline in opercular activity (Table 4). 
Table 2: Physical parameters of the water samples

\begin{tabular}{lllllc}
\hline Location & $\mathrm{pH}$ & $\begin{array}{l}\text { Conductivity } \\
(\mathrm{mS} / \mathrm{cm})\end{array}$ & $\begin{array}{l}\text { Total Dissolved } \\
\text { Solids }(\mathrm{ppm})\end{array}$ & $\begin{array}{l}\text { Free Carbon } \\
\text { dioxide }(\mathrm{ppm})\end{array}$ & $\begin{array}{l}\text { Dissolved Oxygen } \\
(\mathrm{ppm})\end{array}$ \\
\hline Malini Beel & 5.80 & 0.46 & 0.29 & 26 & 3.50 \\
Ashram Road & 6.10 & 0.32 & 0.21 & 13 & 2.50 \\
Deb para & 4.79 & 0.31 & 0.23 & 15 & 3.20 \\
Shishumandir School & 5.60 & 0.16 & 0.12 & 20 & 3.27 \\
Tapaban Nagar & 5.30 & 0.07 & 0.03 & 13 & 2.20 \\
Chirukandi & 4.86 & 0.39 & 0.26 & 13 & 2.80 \\
PHE water & 7.20 & 0.50 & 0.30 & 14 & 4.60 \\
\hline
\end{tabular}

Table 3: Identification of predominant bacteria, present in the water sample

\begin{tabular}{|c|c|c|c|c|c|c|c|c|}
\hline Location & $\begin{array}{l}\text { Gram } \\
\text { Staining }\end{array}$ & $\begin{array}{l}\text { Oxidase } \\
\text { test }\end{array}$ & $\begin{array}{l}\text { Catalase } \\
\text { test }\end{array}$ & $\begin{array}{l}\text { Indole } \\
\text { test }\end{array}$ & $\begin{array}{l}\text { Methylred } \\
\text { test }\end{array}$ & $\begin{array}{l}\text { Voges } \\
\text { Proskauer test }\end{array}$ & $\begin{array}{l}\text { Citrate } \\
\text { test }\end{array}$ & $\begin{array}{l}\text { Suspect } \\
\text { organism }\end{array}$ \\
\hline Malini Beel & - & - & + & + & + & - & - & Escherichia coli \\
\hline Ashram Road & - & - & + & - & - & + & + & Klebsiella sp. \\
\hline Deb Para & - & - & + & + & + & - & - & Escherichia coli \\
\hline Shishu Mandir School & - & - & + & + & + & - & - & Escherichia coli \\
\hline Tapaban Nagar & + & - & + & - & - & + & - & Bacillus sp. \\
\hline Chirukandi & - & + & + & - & - & - & + & Pseudomonas sp \\
\hline
\end{tabular}

+ indicates positive tests; - indicates negative tests

Table 4: Observations of fish behavioural pattern in pond water treated fish

\begin{tabular}{|c|c|c|c|c|}
\hline Characteristic & Day 0 & Day 3 & Day 6 & Day 9 \\
\hline Skin texture & $\begin{array}{l}\text { Dark black, } \\
\text { and slimy skin }\end{array}$ & $\begin{array}{l}\text { Some fishes started } \\
\text { becoming pale white }\end{array}$ & $\begin{array}{l}\text { Most of the fishes have } \\
\text { become pale, and skin } \\
\text { mucus content has reduced }\end{array}$ & $\begin{array}{l}\text { All the fishes became } \\
\text { completely pale, and } \\
\text { skin with no mucus }\end{array}$ \\
\hline Swimming pattern & $\begin{array}{l}\text { Dorsal } \\
\text { surface upward }\end{array}$ & $\begin{array}{l}\text { The speed of } \\
\text { swimming has reduced } \\
\text { surface upward }\end{array}$ & $\begin{array}{l}\text { The speed of swimming has } \\
\text { slowed down, with ventral } \\
\text { at the bottom of the container }\end{array}$ & $\begin{array}{l}\text { Swimming has completely } \\
\text { stopped, and fishes settled }\end{array}$ \\
\hline Feeding pattern & $\begin{array}{l}\text { Frequent visit to } \\
\text { the water surface } \\
\text { is supplied }\end{array}$ & $\begin{array}{l}\text { Frequent visit to the } \\
\text { water surface when } \\
\text { food is supplied }\end{array}$ & $\begin{array}{l}\text { Feeding has slowed down. A lesser } \\
\text { number of visits when food to the water } \\
\text { surface even when food is supplied }\end{array}$ & $\begin{array}{l}\text { Feeding has } \\
\text { completely stopped }\end{array}$ \\
\hline Operculum movement & Normal & Vigorous & Slower & Slower \\
\hline Activeness & $\begin{array}{l}\text { Very active, and } \\
\text { noisy at night }\end{array}$ & $\begin{array}{l}\text { Some fishes have } \\
\text { become less active }\end{array}$ & Very less & Completely stopped \\
\hline
\end{tabular}

Table 5: Mortality rate of the fishes

\begin{tabular}{lllll}
\hline Location & $\begin{array}{l}\text { Number of fishes } \\
\text { alive (Day 0) }\end{array}$ & $\begin{array}{l}\text { Number of fishes } \\
\text { alive (Day 3) }\end{array}$ & $\begin{array}{l}\text { Number of fishes } \\
\text { alive (Day 6) }\end{array}$ & $\begin{array}{l}\text { Number of fishes } \\
\text { alive (Day 9) }\end{array}$ \\
\hline Malini Beel & 5 & 4 & 2 & 1 \\
Ashram Road & 5 & 2 & 0 & 0 \\
Deb Para & 5 & 3 & 2 & 1 \\
Shishu Mandir School & 5 & 4 & 3 & 1 \\
Tapaban Nagar & 5 & 2 & 1 & 0 \\
Chirukandi & 5 & 0 & 0 & 0 \\
PHE water & 5 & 5 & 4 & 3 \\
\hline
\end{tabular}

The hostile environment of the pond water ultimately led to their abnormal mortality rate (Austin, 1998) (Table 5). However, the fishes kept in PHE water container also showed the changes mentioned above, but much later than those kept in the pond water samples.

$\mathrm{RBC}$ and WBC count of all the fishes were performed on Day 0 and were found to be in normal range. However, on day 10, a marked decline in RBC count was observed in pond water treated fishes, which was found to be 0.95 to $0.97 \times 10^{6} \mathrm{~mm}^{-3}$ (Table 6). The control fishes also showed a marginal decline in RBC count from $1.41 \pm 0.03 \times 10^{6}$ (Day 0 ) $\mathrm{mm}^{-3}$ to $1.26 \pm 0.02 \times 10^{6} \mathrm{~mm}^{-3}$ (Day 10), probably due to competitive pressure and container effect (Doyle and Talbot, 1986). RBC count declined at a greater degree in pond water treated fishes indicates a high degree of pollution. Several studies on different fish species such as Amblyceps mangois (Nath, 2016), Salvalinus fontinalis (Holcombe et al., 1976), Colisa fasciatus (Srivastava and Mishra, 1979) also revealed a decline in $\mathrm{RBC}$ count due to water contamination. WBC count in all the containers treated with pond water showed a drastic increase on Day 10 which was found to be $13.55 \times 10^{3} \mathrm{~mm}^{-3}$ to $13.87 \times 10^{3} \mathrm{~mm}^{-3}$ (Table 6). This may due to increased antibody production and recovery from infections (Velmurugan et al., 2016). 
Table 6: Result of the haematological study of fish

\begin{tabular}{|c|c|c|c|c|c|c|}
\hline \multirow[b]{2}{*}{ Location } & \multicolumn{3}{|c|}{ RBC count $\left(\times 10^{6} \mathrm{~mm}^{-3}\right)$} & \multicolumn{3}{|c|}{ WBC count $\left(\times 10^{3} \mathrm{~mm}^{-3}\right)$} \\
\hline & Day 0 & Day 5 & Day 10 & Day 0 & Day 5 & Day 10 \\
\hline Malini Beel & $1.26 \pm 0.02$ & $1.14 \pm 0.02$ & $0.95^{*}$ & $7.8 \pm 0.03$ & $9.23 \pm 0.05$ & $13.87^{*}$ \\
\hline Ashram Road & $1.41 \pm 0.02$ & $1.12 \pm 0.01$ & - & $8.1 \pm 0.02$ & $9.36 \pm 0.02$ & - \\
\hline Deb Para & $1.38 \pm 0.02$ & $1.13 \pm 0.02$ & $0.95^{*}$ & $7.6 \pm 0.02$ & $9.19 \pm 0.02$ & $13.76^{*}$ \\
\hline Shishu Mandir School & $1.33 \pm 0.02$ & $1.16 \pm 0.02$ & $0.97^{*}$ & $7.8 \pm 0.02$ & $8.96 \pm 0.01$ & $13.55^{*}$ \\
\hline Tapaban Nagar & $1.30 \pm 0.01$ & $1.13 \pm 0.01$ & - & $8.2 \pm 0.01$ & $9.38 \pm 0.02$ & - \\
\hline Chirukandi & $1.31 \pm 0.02$ & - & - & $7.8 \pm 0.02$ & - & - \\
\hline PHE water & $1.41 \pm 0.03$ & $1.38 \pm 0.01$ & $1.26 \pm 0.02$ & $7.9 \pm 0.01$ & $8.32 \pm 0.01$ & $9.18 \pm 0.01$ \\
\hline
\end{tabular}

Values are mean \pm standard deviation of 2 replicates; '*' indicates single variable due to mortality of fishes; '-' indicates non-
availability of fishes due to total mortality in that group.

The control fishes, however, showed a marginal increase from $7.9 \pm 0.01 \times 10^{3} \mathrm{~mm}^{-3}$ (Day 0) to $8.32 \pm 0.01 \times 10^{3} \mathrm{~mm}^{-}$ ${ }^{3}$ (Day 5) and finally $9.18 \pm 0.01 \times 10^{3} \mathrm{~mm}^{-3}$ (Day 10). Many researchers also reported hematological changes in Oreochromis aureus (Allen 1994), Anguilla anguilla (Sahan et al., 2007), Heteropneustes fossilis (Srivastav and Roy, 2015) and Anabas testudineus (Velmurugan et al., 2016), which were exposed to industrial effluents, toxic contaminants and heavy metals.

\section{Conclusion}

The present study reveals the degree of pollution in slum areas of Silchar, India, indicating an unhealthy environment for the growth and survival of aquatic organisms. Physical parameters of water samples were not in accordance with the standard values. The abundance of coliform bacteria and less diversity of aquatic microflora indicates the use of the sites for defecation, making the water non-preferable for drinking and household activities. The gradual changes in the physiological behaviour, weight loss and the abnormal mortality rate of fishes during study indicate that the water from the selected sites is not suitable for the survival and growth of fishes. The decline in RBC count and rise in WBC count in the experimental fishes indicates an attack by germs and a high degree of pollution in the selected water bodies. Adequate measures should be taken by the respective residents of the selected areas to minimise the degree of water contamination and use of proper disinfectants, or else the hazardous condition of the water will deteriorate the aquatic biodiversity and create serious health problems in humans.

\section{Acknowledgements}

The authors would like to express their heartiest gratitude to the Department of Zoology and Institutional Biotech Hub (funded by DBT, New Delhi) of Gurucharan College, Silchar for providing laboratory facilities for conducting the present study.

\section{Authors' Contributions}

$\mathrm{RR}, \mathrm{BB}$ and $\mathrm{SN}$ conceived and designed the experiments. RR did the preliminary survey works. RR performed the experiments. SB guided the microbiological experiments. RR and $\mathrm{SN}$ analysed the data. RR wrote the first draft of the manuscript. BB, SB and SN corrected the draft copy. All authors agreed to the final state of the manuscript.

\section{Competing Interests}

The authors declare that they have no competing interests.

\section{Ethics}

This article is original and contains unpublished material. The corresponding author confirms that all of the other authors have read and approved the manuscript and no ethical issues involved.

\section{References}

Allen, P., 1994. Changes in the haematological profile of the cichlid Oreochromis aureus (Steindachner) during acute inorganic mercury intoxication. Comparative Biochemistry and Physiology Part C: Pharmacology, Toxicology Endocrinology, 108: 117-121.

APHA, 1989. Standard Methods for the Examination of Water and Wastewater. 21st Edn., American Public Health Association/American Water Works Association/Water Environment Federation, Washington DC. pp: 15-36.

Austin, B., 1998. The effects of pollution on fish health. J. Applied Microbiol., 85: 234S-242S.

Bardach, J.E., M. Fujiya and A. Holl, 1965. Detergents: effects on the chemical senses of the fish Ictalurus natalis (le Sueur). Science, 148: 1605-1607.

Cabral, J.P., 2010. Water microbiology. Bacterial pathogens and water. Int. J. Environ. Res. Public Health, 7: 3657-3703. 
Cappuccino, J.G. and N. Sherman, 1996. Microbiology: A laboratory manual. The Benjamin/Cummings Publishing Company, Inc., New York, pp: 129-182.

Chakraborty, A. and P. Bhadury, 2015. Effect of Pollution on aquatic microbial diversity. Environmental Microbial Biotechnology, Springer, pp: 53-75.

Culpepper, E.E., L.A. Clayton, C.A. Hadfield, J.E. Arnold and H.M. Bourbon, 2016. Coliform bacteria monitoring in fish systems: Current practices in public aquaria. J. Aquatic Animal Health, 28: 85-90.

Doyle, R.W. and A.J. Talbot, 1986. Artificial selection on growth and correlated selection on competitive behaviour in fish. Canadian J. Fisheries Aquatic Sci., 43: 1059-1064.

Haseena, M., M.F. Malik, A. Javed, S. Arshad and N. Asif et al., 2017. Water pollution and human health. Environ. Risk Assessment Remediation, 1: 16-19.

Holcombe, G.W., D.A. Benoit, E. Leonard and J. McKim, 1976. Long-term effects of lead exposure on three generations of brook trout (Salvelinus fontinalis). J. Fisheries Board Canada, 33: 1731-1741.

Kaper, J.B., A.L. Mills and R.R. Colwell, 1978. Evaluation of the accuracy and precision of enumerating aerobic heterotrophs in water samples by the spread plate method. Applied Environ. Microbiol., 35: 756-761.

Kawamura, G., T. Bagarinao, A.S.K. Yong, C.Y. Chen and S.N.M. Noor et al., 2015. Low pH affects survival, growth, size distribution and carapace quality of the postlarvae and early juveniles of the freshwater prawn Macrobrachium rosenbergii de Man. Ocean Sci. J., 50: 371-379.

Khalili Tilami, S. and S. Sampels, 2018. Nutritional value of fish: Lipids, proteins, vitamins and minerals. Rev. Fisheries Science Aquaculture, 26: 243-253.

Khan, J.R., D. Johansen and P.V. Skov, 2018. The effects of acute and long-term exposure to $\mathrm{CO}_{2}$ on the respiratory physiology and production performance of Atlantic salmon (Salmo salar) in freshwater. Aquaculture, 491: 20-27.

Khan, M.N., A. Islam and M. Hussain, 2003. Marginal analysis of culture of stinging catfish (Heteropneustes fossilis, Bloch): Effect of different stocking densities in earthen ponds. Pak. J. Biol. Sci., 6: 666-670.

Köchling, T., J.L. Sanz, L. Galdino, L. Florencio and M.T. Kato, 2017. Impact of pollution on the microbial diversity of a tropical river in an urbanized region of northeastern Brazil. Int. Microbiol., 20: 11-24.

Ksoll, W.B., S. Ishii, M.J. Sadowsky and R.E. Hicks, 2007. Presence and sources of fecal coliform bacteria in epilithic periphyton communities of Lake Superior. Applied Environ. Microbiology, 73: 3771-3778.
Nath, S., 2016. Effect of paper mill effluents on morphological and hematological indices of Amblyceps mangois. J. Fisheries Aquatic Sci., 11: 225-231.

Poddar, T.K., S. Mukhopadhyay and S.K. Das, 2002. An advanced laboratory manual of zoology. Macmillan Publishers India Limited. pp: 210-213.

Prajapati, B., U. Pandey and P. Prajapati, 2018. Analysis of physico-chemical parameters of water and soil in relation to fish culture of Borina pond, Chargavan, Teh Rithi, Dist. Katni, Madhya Pradesh, India. Analysis, 3: 347-351.

Puvaneswari, S., K. Marimuthu, R. Karuppasamy and M.A. Haniffa, 2009. Early embryonic and larval development of Indian catfish, Heteropneustes fossilis. Eur. Asian J. BioSciences, 3: 84-96.

Sahan, A., T. Altun, F. Çevik, İ. Cengizler and E. Nevsat et al., 2007. Comparative study of some haematological parameters in European eel (Anguilla anguilla L., 1758) caught from different regions of Ceyhan river (Adana, Turkey). Canadian J. Fisheries Aquatic Sciences, 24: 167-171.

Shiddamallayya, N. and M. Pratima. 2008. Impact of domestic sewage on freshwater body. J. Environ. Biology, 29: 303-308.

Srivastav, A.K. and D. Roy, 2015. Effects of malachite green (Triarylmethane dye) and Pyceze (Bronopol) on the hematological parameters of a freshwater catfish Heteropneustes fossilis (Bloch). Int. J. Fish Aqua Stud., 2: 119-122.

Srivastava, A. and S. Mishra, 1979. Blood dyscrasia in a teleost, Colisa fasdatus after acute exposure to sublethal concentrations of lead. J. Fish Biology, 14: 199-203.

Talwar, P.K., 1991. Inland fishes of India and adjacent countries. CRC Press.

Thirumalini, S. and K. Joseph, 2009. Correlation between electrical conductivity and total dissolved solids in natural waters. Malaysian J. Sci., 28: 55-61.

Velmurugan, B., E.I. Cengiz, P. Senthilkumaar, E. Uysal and A. Satar, 2016. Hematological parameters of freshwater fish Anabas testudineus after sublethal exposure to cypermethrin. Environ. Pollut. Prot, 1: 32-39.

Wurts, W.A. and R.M. Durborow, 1992. Interactions of $\mathrm{pH}$, carbon dioxide, alkalinity and hardness in fish ponds. SRAC Publication No. 464.

\section{Abbreviations}

H. fossilis: Heteropneustes fossilis; PHE: Public Health Engineering; $\mathrm{MnSO}_{4}$; Manganese Sulfate; KI: Potassium Iodide; MR: Methyl Red; VP: Voges Proskauer; TDS: Total Dissolved Solids; DO: Dissolved Oxygen; RBC: Red Blood Corpuscle; WBC: White Blood Cell 